\title{
Halocline water modification and along-slope advection at the Laptev Sea continental margin
}

\author{
D. Bauch ${ }^{1}$, S. Torres-Valdes ${ }^{2}$, I. Polyakov ${ }^{3}$, A. Novikhin ${ }^{4}$, I. Dmitrenko ${ }^{5}$, J. McKay ${ }^{6}$, and A. Mix ${ }^{6}$ \\ ${ }^{1}$ GEOMAR Helmholtz Centre for Ocean Research Kiel, Wischhofstr. 1-3, 24148 Kiel, Germany \\ ${ }^{2}$ Ocean Biogeochemistry and Ecosystems, National Oceanography Centre (NOC), European Way, Southampton, \\ SO14 3ZH, UK \\ ${ }^{3}$ International Arctic Research Center and College of Natural Science and Mathematics, University of Alaska Fairbanks, \\ Fairbanks, Alaska, USA \\ ${ }^{4}$ Arctic and Antarctic Research Institute, St. Petersburg, Russia \\ ${ }^{5}$ Centre for Earth Observation Science, University of Manitoba, Winnipeg, Manitoba, Canada \\ ${ }^{6}$ College of Earth, Ocean and Atmospheric Sciences, Oregon State University, Corvallis, Oregon, USA
}

Correspondence to: D. Bauch (dbauch@geomar.de)

Received: 23 August 2013 - Published in Ocean Sci. Discuss.: 12 September 2013

Revised: 13 January 2014 - Accepted: 21 January 2014 - Published: 25 February 2014

\begin{abstract}
A general pattern in water mass distribution and potential shelf-basin exchange is revealed at the Laptev Sea continental slope based on hydrochemical and stable oxygen isotope data from the summers 2005-2009. Despite considerable interannual variations, a frontal system can be inferred between shelf, continental slope and central Eurasian Basin waters in the upper $100 \mathrm{~m}$ of the water column along the continental slope. Net sea-ice melt is consistently found at the continental slope. However, the sea-ice meltwater signal is independent from the local retreat of the ice cover and appears to be advected from upwind locations.

In addition to the along-slope frontal system at the continental shelf break, a strong gradient is identified on the Laptev Sea shelf between $122^{\circ} \mathrm{E}$ and $126^{\circ} \mathrm{E}$ with an eastward increase of riverine and sea-ice related brine water contents. These waters cross the shelf break at $\sim 140^{\circ} \mathrm{E}$ and feed the low-salinity halocline water (LSHW, salinity $S<33$ ) in the upper $50 \mathrm{~m}$ of the water column. High silicate concentrations in Laptev Sea bottom waters may lead to speculation about a link to the local silicate maximum found within the salinity range of $\sim 33$ to 34.5 , typical for the Lower Halocline Water (LHW) at the continental slope. However brine signatures and nutrient ratios from the central Laptev Sea differ from those observed at the continental slope. Thus a significant contribution of Laptev Sea bottom waters to the LHW at the continental slope can be excluded. The silicate
\end{abstract}

maximum within the LHW at the continental slope may be formed locally or at the outer Laptev Sea shelf. Similar to the advection of the sea-ice melt signal along the Laptev Sea continental slope, the nutrient signal at 50-70 m water depth within the LHW might also be fed by advection parallel to the slope. Thus, our analyses suggest that advective processes from upstream locations play a significant role in the halocline formation in the northern Laptev Sea.

\section{Introduction}

Numerous changes are predicted for the Arctic environment in the near future: models suggest that the permanent Arctic sea-ice cover may become seasonal within the next few decades (e.g. Overland and Wang, 2013), affecting also the perennial sea-ice dynamics on the Arctic shelves. In addition, precipitation and the freshwater input from rivers may increase (Zhang et al., 2013). Impact of these and other processes related to and defining high-latitude freshwater balances may be critical for the state of the Arctic halocline, which is $\mathrm{a} \sim 150 \mathrm{~m}$ thick layer with typical temperatures close to freezing and salinities sharply increasing with depth. The halocline insulates the Arctic sea-ice cover from impact of underlying Atlantic Water heat due to its strong stratification, thus playing a fundamental climatological role (Rudels 
et al., 1996). Hence, in light of climate change and its potential impacts on the Arctic Ocean halocline, further knowledge is needed on its current structure and the processes and regions involved in its formation.

The so-called Lower Halocline Water (LHW) is formed in the Eurasian sector of the Arctic Ocean by modification of Atlantic Water over the Barents and northern Kara seas (Aagaard et al., 1981; Steele and Boyd 1998; Rudels, 2004) and near the continental slope north of Svalbard (Rudels, 2004). The LHW has salinities of $\sim 33$ to 34.5 and is close to the freezing point of sea water. Near the continental margin temperatures of LHW are slightly higher (Dmitrenko et al., 2011). Overlying the LHW are low-salinity halocline waters (LSHW), with salinities $<33$. LSHW contains large quantities of Siberian river water and originate either in the Laptev Sea (Bauch et al., 2009, 2011b) or in the East Siberian Sea (Anderson et al., 2013). The salinity of shelf waters is variable and relatively low, while temperature may vary from close to the freezing point to seasonally high temperatures of up to $5^{\circ} \mathrm{C}$. Therefore, shelves are not only a source of freshwater but potentially also a source of heat which may become increasingly important as summer sea-ice extent continues to decrease.

In this study we use $\delta^{18} \mathrm{O}$-derived freshwater fractions and nutrient data to investigate the water mass structure at the Laptev Sea continental margin, discuss their origin and the potential exchange of Laptev Sea shelf water with Arctic Ocean halocline waters. Freshwater fractions and nutrient distributions in the upper $100 \mathrm{~m}$ of the water column allow us to distinguish surface and bottom shelf waters, waters at the continental slope, as well as waters off-slope in the basin. These water masses are only partially discernible using salinity and temperature distributions. While $\delta^{18} \mathrm{O}$-derived river water fractions closely follow salinity and to some extent also temperature distributions, the signal of $\delta^{18} \mathrm{O}$-derived sea-ice meltwater is largely independent from either. That is why the analysis presented here is of importance. Of particular interest is whether slope waters at the continental slope are of local origin or whether these are laterally advected from elsewhere. To answer this question, we explore tracer signatures (i.e. river water fractions, sea-ice related brine and nutrient signatures) with the aim of identifying and distinguishing Laptev Sea shelf, slope or basin halocline waters. We focus on the salinity ranges within the Arctic Ocean halocline that may potentially be influenced by Laptev Sea shelf waters. We also address the potential contribution of Laptev Sea shelf waters to LHW.

\section{Data and method}

Stable oxygen isotope and nutrient analyses were conducted on water samples taken at oceanographic rosette/CTD stations (Fig. 1). Data for the Eurasian continental margin were collected in summer from 2005 to 2009 (KD05,

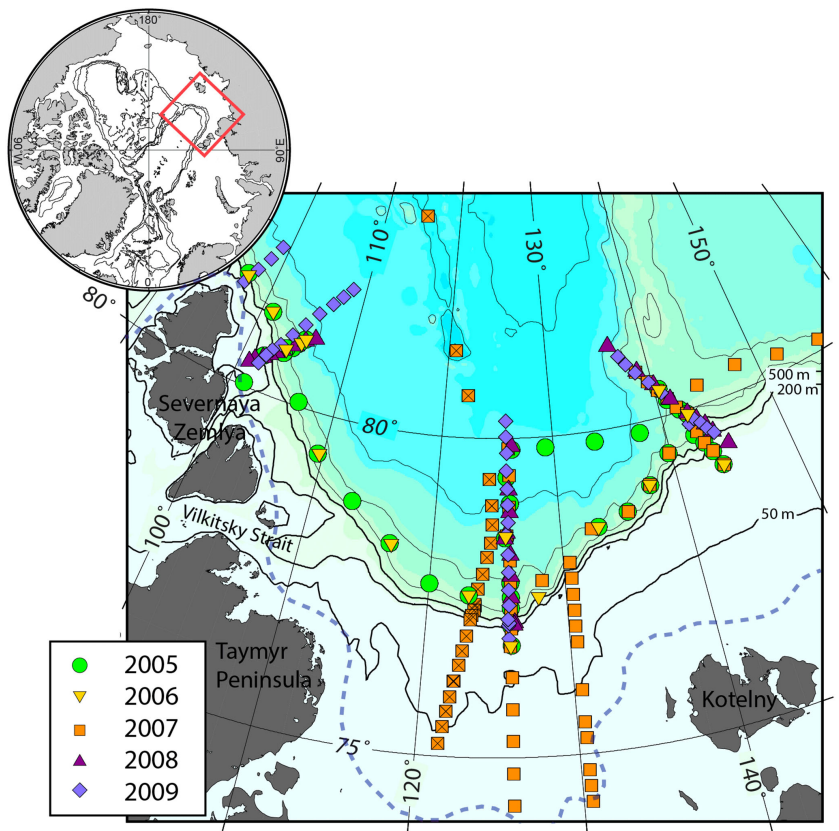

Fig. 1. Geographical distribution of stations near the Laptev Sea continental slope. Shown are all stations from NABOS expeditions taken in summers 2005 to 2009 and during Polarstern expedition PS07 taken in summer 2007 (additionally marked with a cross). Black solid lines show the position of the $500 \mathrm{~m}, 200 \mathrm{~m}$ and $50 \mathrm{~m}$ isobaths that indicates the shelf break, and mark the northern borders of the outer and central Laptev Sea shelf, respectively. The stippled line marks the average position of the fast ice edge. Between pack ice and fast ice edge, flaw polynyas are formed during winter (e.g., Krumpen et al., 2013).

KD06, VB07, KD08, KD09) within the framework of the Nansen and Amundsen Basins Observational System (NABOS) program (expedition technical reports are available at http://nabos.iarc.uaf.edu/cruise/reports.php) and Polarstern expedition ARKXXII/2 (referred to hereafter as PS07) in summer 2007 (see expedition reports in Schauer, 2008). Data from the Laptev Sea shelf are based on water sampling within the framework of TRANSDRIFT expeditions in summers 2007 (IP07), 2008 (IP08) and 2009 (YS09) (see expedition reports in Kassens and Volkmann-Lark, 2010). Water samples were in all cases taken with a conductivitytemperature-depth (CTD)-rosette with an accuracy of at least $\pm 0.002 \mathrm{~S} \mathrm{~m}^{-1}$ in conductivity and $\pm 0.005^{\circ} \mathrm{C}$ in temperature.

Our measurement precision for all presented $\delta^{18} \mathrm{O}$ is at least $\pm 0.04 \%$ o (Bauch et al., 2010, 2011a, b, 2013). All $\mathrm{H}_{2}^{18} \mathrm{O} / \mathrm{H}_{2}^{16} \mathrm{O}$ ratios were calibrated with a VSMOW standard and reported in the usual $\delta$-notation (Craig, 1961). The NABOS stable isotope data from 2008 and 2009 data are presented for the first time. Both data sets were analyzed at the Stable Isotope Laboratory of the College of Earth, Ocean, and Atmospheric Sciences at Oregon State University 
(Corvallis, USA) applying the $\mathrm{CO}_{2}$-water isotope equilibration technique and analyzed by dual inlet mass spectrometry on a DeltaPlus XL. Laptev Sea data for 2008 and 2009 are published in Bauch et al. (2013). Data from NABOS 2005 and 2006 were published in condensed form in Bauch et al. (2011a). Data taken on three expeditions in 2007 (IP07, VB07, PS07) were published separately for the basin (Bauch et al., 2011b) and the shelf (Bauch et al., 2010).

NABOS 2005 and 2006 water samples for silicate (here after referred to as $\mathrm{Si})$, total nitrate $\left(\mathrm{NO}_{3}+\mathrm{NO}_{2}\right.$, hereafter referred to as $\mathrm{N}$ ) and phosphate (hereafter referred to as $\mathrm{P}$ ) were collected in $50 \mathrm{~mL}$ plastic bottles and frozen at $-20^{\circ} \mathrm{C}$ until analysis. Analyses were carried out within one month with photometric techniques using a SKALAR San Plus nutrient autoanalyzer (in range: $2-100 \mathrm{ppb}$ ) at the Otto-Schmidt Laboratory (St. Petersburg, Russia) following "Skalar" methods (US Environmental Protection Agency, 1983). Ammonia was not measured but is considered to be usually low in the area (Nitishinski et al., 2007). Data from 2005 show a systematic deviation from the Atlantic Water N / P correlation (e.g. Jones et al., 1998; see Fig. 8) that may be a systematic error. During NABOS 2007 and 2008, Si, N and P were analysed within $30 \mathrm{~min}$ of sample collection using a continuousflow Skalar San plus autoanalyser. Precision based on standard measurements and randomly selected replicates showed a variation of $<3.5 \%$ from mean concentrations (for further details see NABOS expedition reports). During NABOS 2009 samples were analysed on board for $\mathrm{Si}, \mathrm{N}$ and $\mathrm{P}$ using colorimetric methods following Bordovsky and Ivanenkov (1992). Quality of N and P data for this 2009 data set is not sufficiently high to be used here.

\section{Mass balance analysis of freshwater sources}

Based on a mass, $\delta^{18} \mathrm{O}$ and salinity balance, the different freshwater sources can be separated. The major freshwater sources are river water and sea-ice meltwater (SIM), both of which originate mainly from the Arctic shelf areas. Freshwater fractions in each water sample can be estimated using mass balance calculations as was previously done in the central Arctic Ocean (e.g., Östlund and Hut, 1984; Bauch et al., 1995; Ekwurzel et al., 2001; Yamamoto-Kawai et al., 2008; Newton et al., 2013) and shelf regions (Macdonald et al., 1995; Cooper et al., 1997; Bauch et al., 2005). It is assumed that each summer sample is a mixture between Atlantic derived water $\left(f_{\mathrm{mar}}\right)$, river runoff $\left(f_{\mathrm{r}}\right)$, and sea-ice meltwater $\left(f_{\mathrm{SIM}}\right)$. Technically $\mathrm{f}_{\mathrm{r}}$ refers to meteoric water but as river runoff dominates in the study area we refer to river runoff for simplicity. The mass balance is governed by the following equations:
Table 1. End-member values used in mass balance calculations*.

\begin{tabular}{lrr}
\hline End-member & Salinity & $\delta^{18} \mathrm{O}(\% \mathrm{o})$ \\
Marine $\left(f_{\text {mar }}\right)$ & $34.92(5)$ & $0.3(1)$ \\
River $\left(f_{\mathrm{r}}\right)$ & 0 & $-20(1)$ \\
Sea ice $\left(f_{\text {SIM }}\right)$ & $4(1)$ & surface+2.6 $(1)$ or $-7+2.6(1)$ \\
\hline
\end{tabular}

* Numbers in parentheses are the estimated uncertainties within the last digit in our knowledge of each end-member value.

$$
\begin{gathered}
f_{\mathrm{mar}}+f_{\mathrm{r}}+f_{\mathrm{SIM}}=1, \\
f_{\mathrm{mar}} \cdot S_{\mathrm{mar}}+f_{\mathrm{r}} \cdot S_{\mathrm{r}}+f_{\mathrm{SIM}} \cdot S_{\mathrm{SIM}}=S_{\text {meas }}, \\
f_{\mathrm{mar}} \cdot O_{\mathrm{mar}}+f_{\mathrm{r}} \cdot O_{\mathrm{r}}+f_{\mathrm{SIM}} \cdot O_{\mathrm{SIM}}=O_{\text {meas }}
\end{gathered}
$$

where $f_{\mathrm{mar}}, f_{\mathrm{r}}$, and $f_{\mathrm{SIM}}$ are the fractions of marine water, river runoff, and sea-ice meltwater, respectively, in a water parcel, and $S_{\mathrm{mar}}, S_{\mathrm{r}}, S_{\mathrm{SIM}}, O_{\mathrm{mar}}, O_{\mathrm{r}}$ and $O_{\mathrm{SIM}}$ are the corresponding salinities and $\delta^{18} \mathrm{O}$ values (Table 1). $S_{\text {meas }}$ and $O_{\text {meas }}$ are the measured salinity and $\delta^{18} \mathrm{O}$ of the water samples. For further details on the selection of end-members applicable for the Laptev Sea and the Eurasian Basin regions refer to Bauch et al. (2010, 2011b). As only stations west of $150^{\circ} \mathrm{E}$ are discussed no additional analysis for the influence of Pacific derived waters is necessary (Abrahamsen et al., 2009; Bauch et al., 2011b).

All fractions are net values reconstructed from the $\delta^{18} \mathrm{O}$ and salinity signatures of each sample, and reflect the timeintegrated effects on the sample volume over the residence time of the water. Negative SIM fractions $\left(f_{\text {SIM }}\right)$ reflect the amount of water removed by sea-ice formation and are proportional to the subsequent addition of brines to the water column. SIM fractions may be negative during summer season sampling if the winter signal exceeds the summer signal. An uncertainty of $\pm 0.3 \%$, resulting from analytical errors associated with $\delta^{18} \mathrm{O}$ and salinity measurements, is estimated for each fraction. An additional systematic error depends on the exact choice of end-member values. When end-member values are varied within the estimated uncertainties (Table 1), both fractions are shifted by up to $\sim 1 \%$, but results are always qualitatively conserved even when tested with extreme end-member variations (see Bauch et al., 2011b).

Inventories of river water and sea-ice meltwater were calculated by integrating each fraction from the surface down to $150 \mathrm{~m}$ or bottom depth, when the depth is less than $150 \mathrm{~m}$. As most of the river water and sea-ice meltwater are found within the upper 50-100 $\mathrm{m}$ water depth, the choice of the integration depth is not critical to relative values, but rather adds a systematic offset. When an integration depth of $100 \mathrm{~m}$ is chosen instead of $150 \mathrm{~m}$, the offset in both fractions is generally below $15 \%$ of the total inventory value and is below $\sim 0.7 \mathrm{~m}$ and $\sim 0.3 \mathrm{~m}$ in river and sea-ice inventory values, respectively. Integration depths on the shelf are mostly at $\sim 50 \mathrm{~m}$ water depth or less but there is no systematic trend 


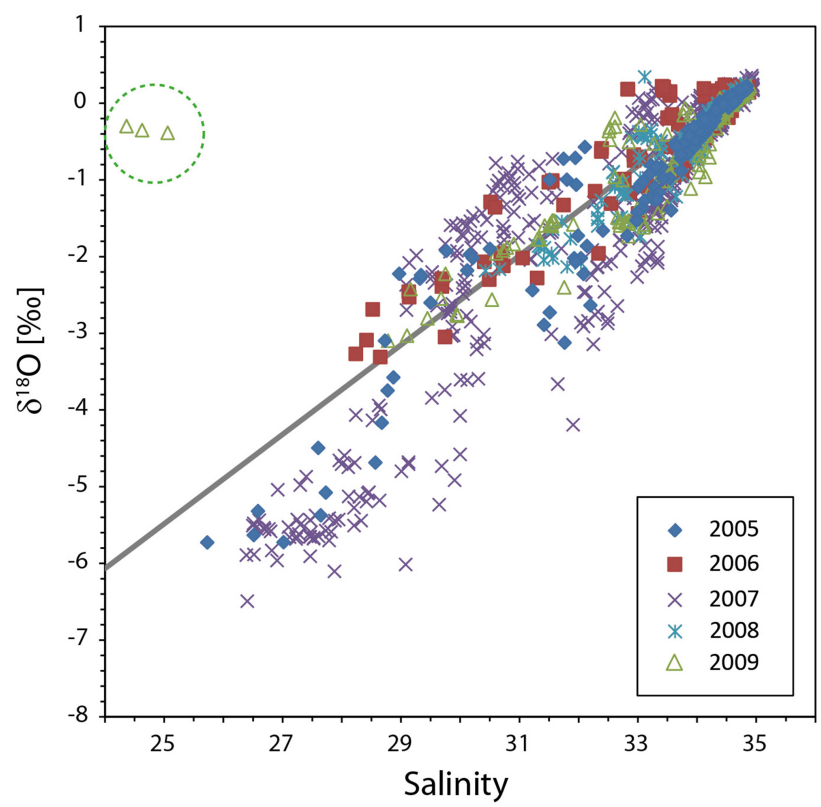

Fig. 2. $\delta^{18} \mathrm{O}$ versus salinity in the upper $150 \mathrm{~m}$ of the water column for data taken during NABOS 2005-2009 and PS07 near the Laptev Sea continental slope (Fig. 1). The direct mixing line between Atlantic Water and river water endmembers (see Table 1) is shown in gray for reference. The stippled circle highlights anomalous data from the upper $30 \mathrm{~m}$ from a station north of Severnaya Zemlya (KD-67-09; $\left.101.8^{\circ} \mathrm{E}, 80.4^{\circ} \mathrm{N}\right)$.

in river and sea-ice inventories with bottom depth. Inventory values represent the thickness of the layer of pure river water or sea-ice meltwater contained in the water column. Negative inventory values for sea-ice meltwater represent the thickness of the layer removed from the water column as sea ice.

\section{Results}

Along the Laptev Sea continental margin $\delta^{18} \mathrm{O}$ and salinity show a first order linear correlation and strong interannual variations (Fig. 2). Low salinity ( $26-28)$ waters are found in 2005 and 2007 only. Sampling in 2007 captures low salinity shelf waters with stations taken relatively far south $\left(\sim 74^{\circ} \mathrm{N}\right)$ onto the central shelf (see Fig. 1), explaining the observed low salinities within the 2007 data set. In 2005 low salinities between $\sim 26$ and 28 were found at $\sim 142^{\circ} \mathrm{E}$ close to the continental slope where a cross-slope section was sampled each year (Fig. 1). However, only 2005 observations at $\sim 142^{\circ} \mathrm{E}$ showed such low salinities and corresponding low $\delta^{18} \mathrm{O}$ values (Fig. 2) which can be linked to enhanced export of central Laptev Sea shelf waters during this year (Bauch et al., 2011a).

The oceanographic section at $\sim 126^{\circ} \mathrm{E}$ documents the interannual variability across the continental margin from the central Laptev Sea to the deep basin (Fig. 3). Relatively fresh and warm surface waters containing high river water fractions $\left(f_{\mathrm{r}}\right)$ with maximum values at the surface can be seen to a variable extent over the Laptev Sea shelf in all years. In the upper $50 \mathrm{~m}$ of the water column salinity increases from the shelf break towards the basin, and river water fractions decrease accordingly. The calculated sea-ice meltwater fractions are mostly negative for shelf waters. Sea-ice related brine signals (negative $f_{\text {SIM }}$ ) are in general largest in the bottom layer with the exception of summer 2007, when they were largest near the surface (for details, see Bauch et al., 2010). Negative $f_{\text {SIM }}$ signals in the basin are generally lower than on the shelf, but show a distinct maximum at about 30 to $50 \mathrm{~m}$ water depth off the shelf break. A thin surface layer of sea-ice meltwater (positive $f_{\mathrm{SIM}}$ ) extends from the basin, over the shelf break and partly onto the shelf (subject to interannual variation) southwards to $\sim 77-75^{\circ} \mathrm{N}$ (Fig. 3). The distribution of silicate shows a maximum over the shelf within the low salinity surface layer and a second maximum at the bottom over the shelf. At the shelf break a discontinuity in temperature and the sea-ice related brine signal is visible at about $30-50 \mathrm{~m}$ (Fig. 3; at $126^{\circ} \mathrm{E}, \sim 77^{\circ} \mathrm{N}$ ). Silicate values are low off the shelf break but show a maximum at the bottom directly at the shelf break (Fig. 3, at $\sim 50-70 \mathrm{~m}$ depth and $\sim 76.7^{\circ} \mathrm{N}$; see also Table 2).

In summer 2007, oceanographic cross-slope sections were taken at $\sim 122^{\circ} \mathrm{E}, 126^{\circ} \mathrm{E}, 130^{\circ} \mathrm{E}$ and $\sim 142^{\circ} \mathrm{E}$ (Figs. 3 and 4). This quasi-synoptic view of water masses at the continental shelf break of the Laptev Sea show strong gradients between low salinity shelf water masses in the south and relatively high salinity halocline waters in the north. The extent of the shelf water mass defined by $\sim-5 \%$ in SIM fraction (with river water fractions between $\sim 10$ and $15 \%$ ) shifts from relatively far south $\left(\sim 75-76^{\circ} \mathrm{N}\right)$ in the western part $\left(122^{\circ} \mathrm{E}\right.$ and $\left.126^{\circ} \mathrm{E}\right)$ to far north $\left(\sim 77^{\circ} \mathrm{N}\right.$ and $\left.\sim 81^{\circ} \mathrm{N}\right)$ in the eastern part $\left(130^{\circ} \mathrm{E}\right.$ and $\left.142^{\circ} \mathrm{E}\right)$ of the Laptev Sea. Therefore shelf waters cross the shelf break $\left(\sim 78-79^{\circ} \mathrm{N}\right)$ at $\sim 140^{\circ} \mathrm{E}$ (Fig. 4).

Freshwater inventories are calculated for the upper $150 \mathrm{~m}$ water depth in order to quantify the freshwater amount enclosed within the water column. Inventory values of river water show the highest values in the eastern Laptev Sea near the main outflow of the Lena River and off the eastern Laptev Sea continental slope (Fig. 5). Meltwater inventories are negative north and south of the continental shelf break and at the eastern Laptev Sea shelf break (Fig. 5). Positive sea-ice meltwater (SIM) inventories are generally found near the continental slope of the western and central Laptev Sea (Fig. 5).

\section{Discussion}

Despite substantial interannual variability, all parameters show a consistent water mass structure (Fig. 6, Table 3). We hypothesize that the discontinuity seen at the Laptev Sea continental slope indicate a frontal system maintained by lateral advection, for example, of the shelf break branch of the Arctic Circumpolar Boundary Current (ACBC) (Woodgate 

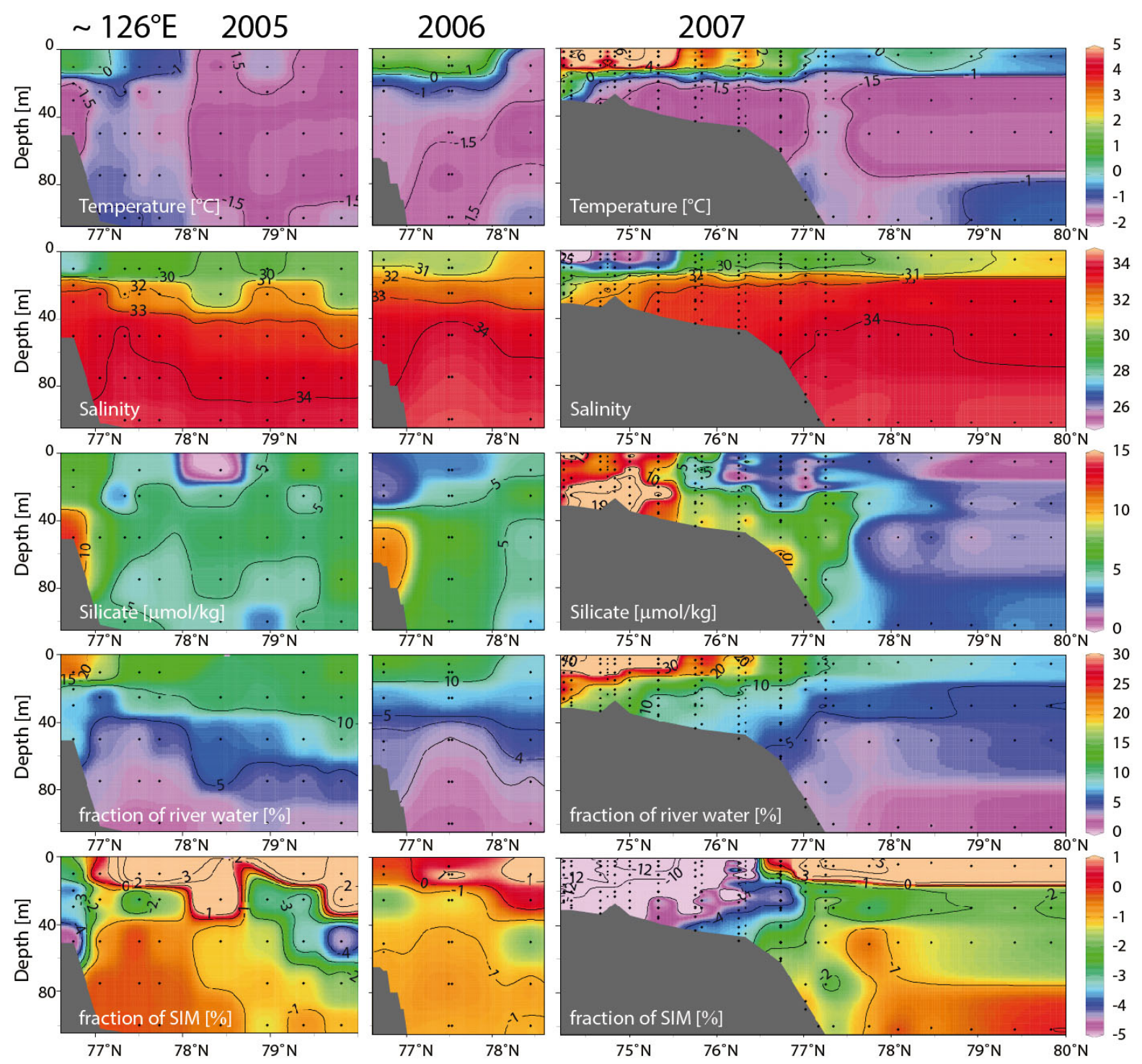

Fig. 3a. Oceanographic sections along $126^{\circ}$ E taken in the summers 2005-2009 based on NABOS 2005-2009, TRANSDRIFT 2007-2009 and PS07 data. Shown are temperature, salinity, silicate concentration and $\delta^{18} \mathrm{O} / \mathrm{S}$ derived fractions of river water and sea-ice meltwater. Note that negative fractions of sea-ice meltwater represent the amount of freshwater removed as sea-ice and are proportional to the amount of brine added to the water parcel. For further explanation see text.

et al., 2001; Aksenov, et al., 2011). Our observations define a frontal system between shelf waters in the south, slope waters at the continental shelf break and halocline waters in the north: (i) shelf waters are characterised by extremely high sea-ice and river signals as well as extremely high silicate concentrations; (ii) in the basin and off the continental slope, LHW and LSHW contain both relatively high river and seaice signals, as well as low silicate concentrations; and (iii) at the continental slope, the layer of sea-ice related brine signal seen over the shelf and basin at about $30-50 \mathrm{~m}$ water depth shows a discontinuity and slightly higher temperatures (Figs. 3, 6 and Table 3). In addition, a distinct silicate maximum is found at the bottom at the continental slope (Fig. 3).

\subsection{Laptev Sea SIM signal and $f_{\mathrm{SIM}} / f_{\mathrm{r}}$ signature}

The sea-ice related brine signal (negative SIM) found on the shelf of the Laptev Sea stretches northwards (Fig. 3, most pronounced in 2009) at $\sim 30-50 \mathrm{~m}$ water depth, but there is a discontinuity directly above the continental slope that is also seen in the temperature distribution (Fig. 3). While it is tempting to suggest a direct exchange or entrainment of the negative SIM signal from shelf to basin waters, the salinity ranges within these layers differ by $\sim 0.6-1.2$, being generally higher in the basin. This suggests that the observed negative SIM signals must be of different origin. The only exception is 2005 when the layer with maximal sea-ice 

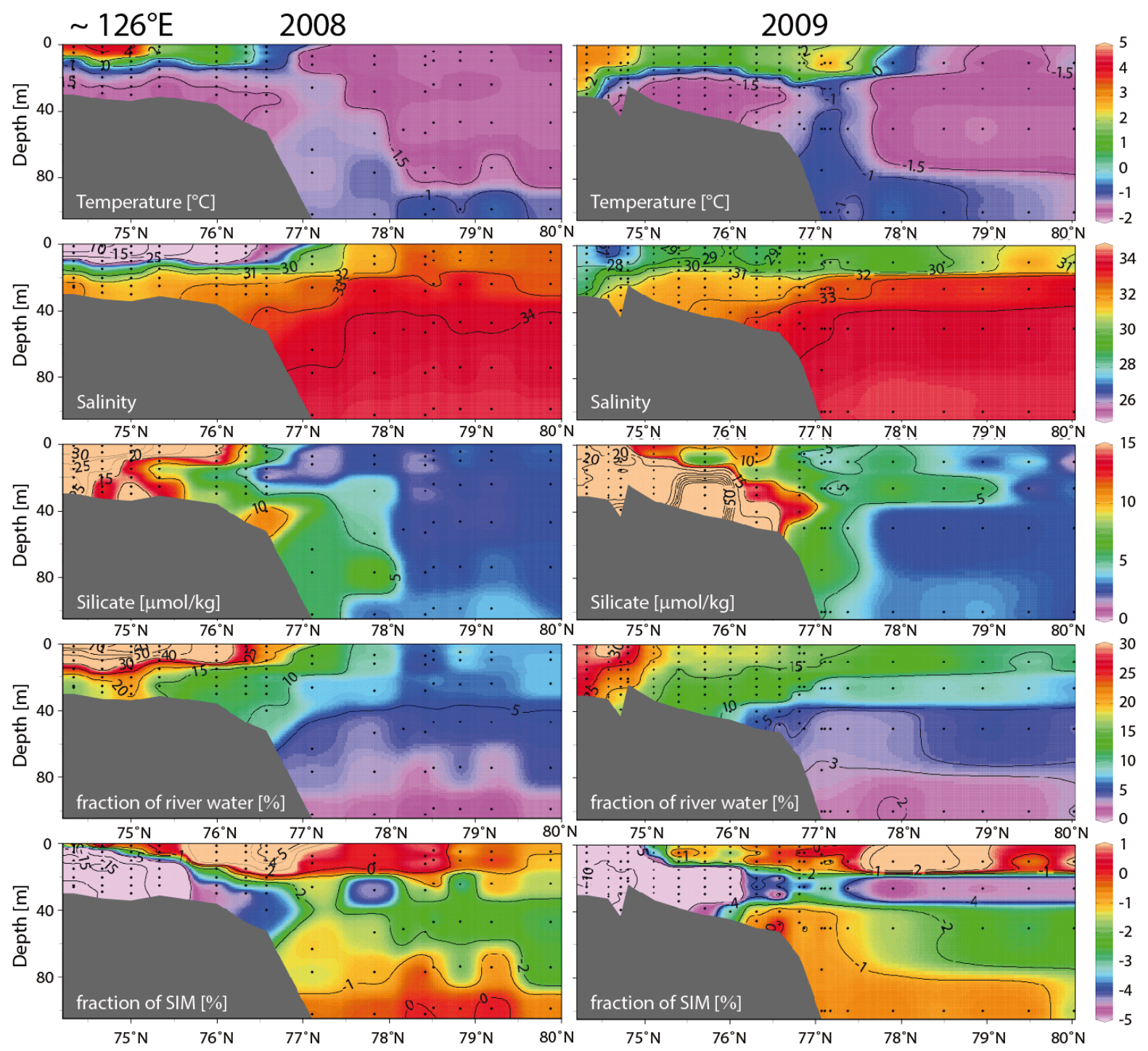

Fig. 3b. Continued.

related brine signal (negative SIM) was fresher in the basin $(S \sim 32.8)$ than near the shelf break $(S \sim 33.5)$. In 2005 the Si maximum also coincides with the sea-ice related brine signal. Atmospheric forcing in 2005 triggered a pronounced export of shelf surface and bottom waters, thus exporting river and sea-ice related brine waters from the eastern Laptev Sea into the basin (Bauch et al., 2011b). We speculate that such a pronounced export may be counterbalanced by advection of high salinity Atlantic-derived waters known to extend onto the outer Laptev Sea shelf sporadically (e.g. Dmitrenko et al., 2010). Given that the negative SIM signal on the Laptev Sea is - to a large extent - the result of winter sea-ice formation within the coastal polynyas, the shelf waters containing a negative SIM signal at salinity of 30 to 32 found at $\sim 30 \mathrm{~m}$ water depth are fed by bottom waters in the central Laptev Sea (Bauch et al., 2012, 2013).
The coastal polynyas produce brine in an area where large fractions of river water are found. Thus, the brine-enriched bottom water produced in Laptev Sea coastal polynyas is characterised by having high fractions of sea-ice related brine (negative $f_{\mathrm{SIM}}$ ) in combination with high river water fractions (Bauch et al., 2011a). Therefore, the correlation of seaice related brine and river water fractions $\left(f_{\mathrm{SIM}} / f_{\mathrm{r}}\right)$ in surface waters at the Laptev Sea shelf break (Fig. 7) shows two clusters that can be assigned to waters formed in either coastal polynyas, with high $f_{\mathrm{r}}$ and low salinities, or polynyas near the continental slope or in open ocean with relatively low $f_{\mathrm{r}}$ and relatively high salinities (Bauch et al., 2011b). The $f_{\text {SIM }} / f_{\mathrm{r}}$ correlation with extremely low river water fractions is not visible off the continental slope of the western Laptev Sea (Fig. 7, see orange circles). This is consistent with the export of brine-enriched bottom waters originating 


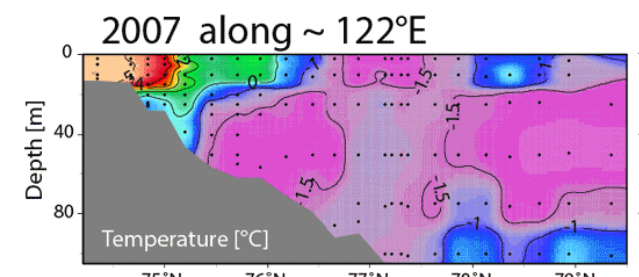

\section{$130^{\circ} \mathrm{E}$}
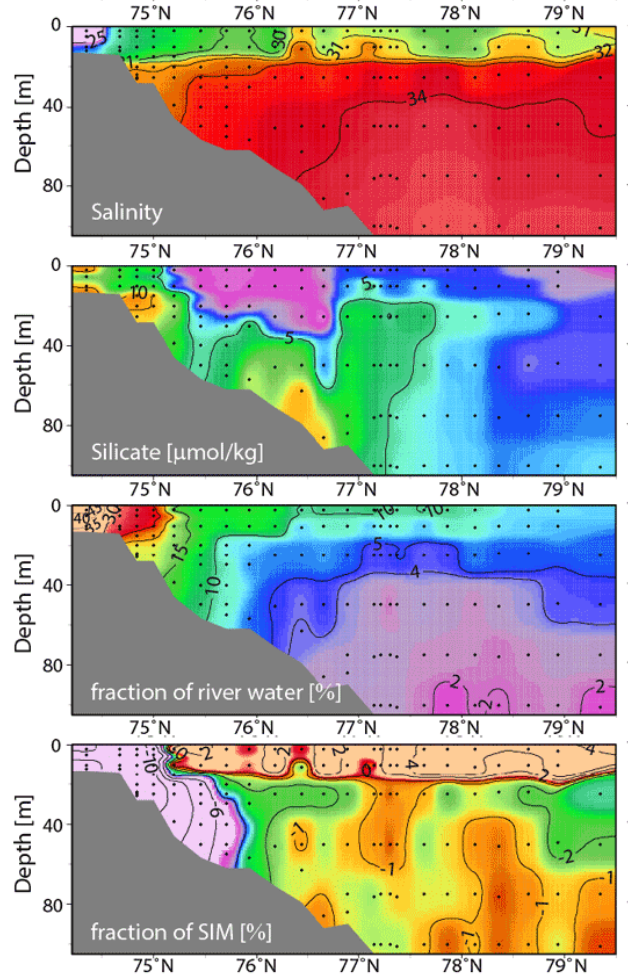

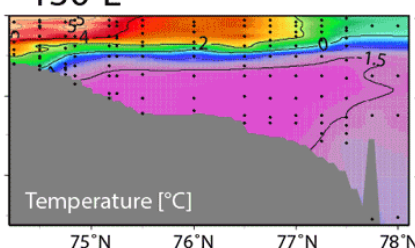

$142^{\circ} \mathrm{E}$
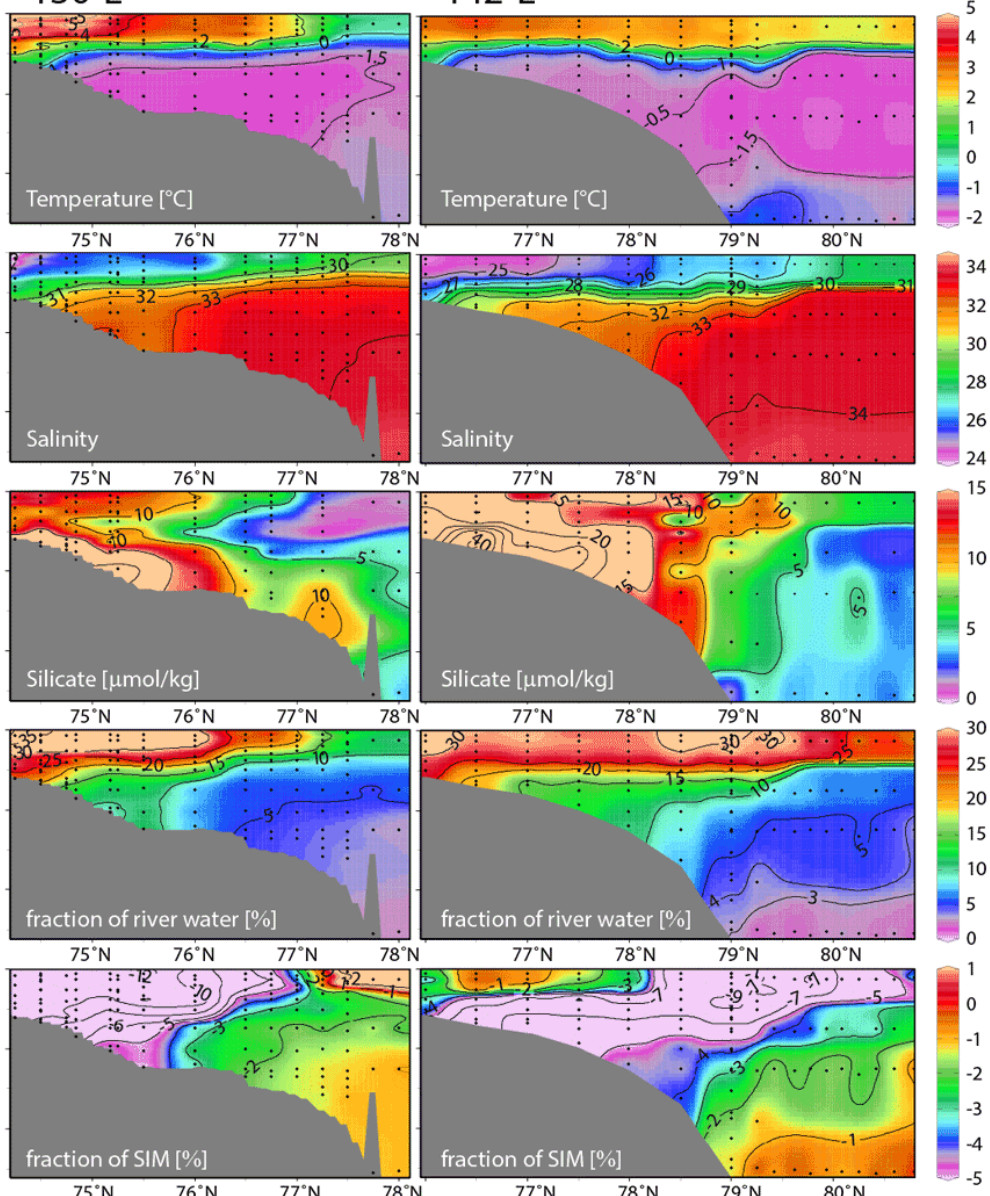

Fig. 4. Oceanographic sections taken in 2007 along $\sim 122^{\circ} \mathrm{E}$ (left), $130^{\circ} \mathrm{E}$ (middle) and $\sim 142^{\circ} \mathrm{E}$ (right) (note that the section taken at $126^{\circ} \mathrm{E}$ in 2007 is shown in Fig. 3). Sections are based on IP07, VB07 and PS07 data.

Table 2. Station data of Si maximum at the Laptev Sea continental slope. Stations are sorted by area $\left(\sim 122^{\circ} \mathrm{E}, \sim 126^{\circ} \mathrm{E}, \sim 130^{\circ} \mathrm{E}\right.$, $\sim 140^{\circ} \mathrm{E}$ ). Given that in 2009 no separate Si maximum was observed at the continental margin, no stations are listed for this year.

\begin{tabular}{|c|c|c|c|c|c|c|c|c|c|c|c|}
\hline Cruise & Station & $\begin{array}{l}\text { Long. } \\
\left({ }^{\circ} \mathrm{E}\right)\end{array}$ & $\begin{array}{l}\text { Lat. } \\
\left({ }^{\circ} \mathrm{N}\right)\end{array}$ & $\begin{array}{r}\text { Bottom } \\
{[\mathrm{m}]}\end{array}$ & $\begin{array}{r}\text { Depth } \\
{[\mathrm{m}]}\end{array}$ & $\begin{array}{r}T \\
{\left[{ }^{\circ} \mathrm{C}\right]}\end{array}$ & $\begin{array}{r}S \\
{[\mathrm{psu}]}\end{array}$ & $\begin{array}{r}\mathrm{Si} \\
{\left[\mu \mathrm{mol} \mathrm{kg}{ }^{-1}\right]}\end{array}$ & $\begin{array}{r}\mathrm{P} \\
{\left[\mu \mathrm{mol} \mathrm{kg}{ }^{-1}\right]}\end{array}$ & {$\left[\mu \mathrm{mol} \mathrm{kg}{ }^{-1}\right]$} & $\begin{array}{r}\delta^{18} \mathrm{O} \\
{[\% o]}\end{array}$ \\
\hline PS07 & 405 & 122.6 & 76.7 & 92 & 86 & -1.33 & 34.13 & 9.5 & 0.79 & 8.2 & -0.30 \\
\hline PS07 & 406 & 122.4 & 76.4 & 79 & 63 & -1.47 & 34.01 & 10.2 & 0.84 & 8.3 & -0.51 \\
\hline KD 05 & 41 & 126.0 & 76.8 & 51 & 50 & -1.78 & 33.56 & 12.5 & 0.51 & 4.4 & -1.40 \\
\hline KD 06 & 1 & 125.9 & 76.7 & 63 & 56 & -1.36 & 33.95 & 12.1 & 0.83 & 7.7 & -0.40 \\
\hline VB07 & 1 & 125.9 & 76.7 & $\sim 70$ & 60 & -1.50 & 33.97 & 9.7 & 0.71 & 8.2 & -0.54 \\
\hline IP07-2 & $4 \mathrm{~L}_{-} 1$ & 125.9 & 76.7 & 62 & 60 & -1.56 & 33.89 & 13.6 & 0.80 & 6.5 & -0.63 \\
\hline IP07-2 & 4L_5 & 125.9 & 76.7 & 62 & 50 & -1.61 & 33.77 & 10.8 & 0.78 & 7.9 & -0.68 \\
\hline IP07-2 & 4L_9 & 125.9 & 76.7 & 62 & 40 & -1.68 & 33.59 & 11.8 & 0.77 & 6.6 & -0.97 \\
\hline IP07-2 & 4L_9 & 125.9 & 76.7 & 62 & 60 & -1.54 & 33.92 & 8.8 & 0.82 & 14.2 & -0.63 \\
\hline IP08-2 & $193 \mathrm{M}$ & 126.1 & 76.6 & 52 & 40 & -1.48 & 33.13 & 11.2 & 0.23 & & -1.59 \\
\hline VB07 & 54 & 130.5 & 77.2 & $\sim 70$ & 63 & -1.53 & 33.92 & 10.3 & 0.74 & 7.4 & -0.64 \\
\hline KD 05 & 30 & 144.0 & 79.0 & 90 & 50 & -1.44 & 33.35 & 10.8 & 0.92 & 5.8 & -1.17 \\
\hline KD 06 & 11 & 144.0 & 79.0 & 90 & 80 & -0.91 & 34.16 & 8.7 & 0.74 & 7.6 & -0.39 \\
\hline IP07-2 & 10 & 143.0 & 78.5 & 68 & 65 & -1.53 & 33.60 & 11.8 & 0.90 & 8.8 & -1.04 \\
\hline IP08-2 & $201 \mathrm{M}$ & 143.0 & 78.0 & 50 & 48 & -1.57 & 32.1 & 16.0 & 0.04 & - & -2.73 \\
\hline
\end{tabular}



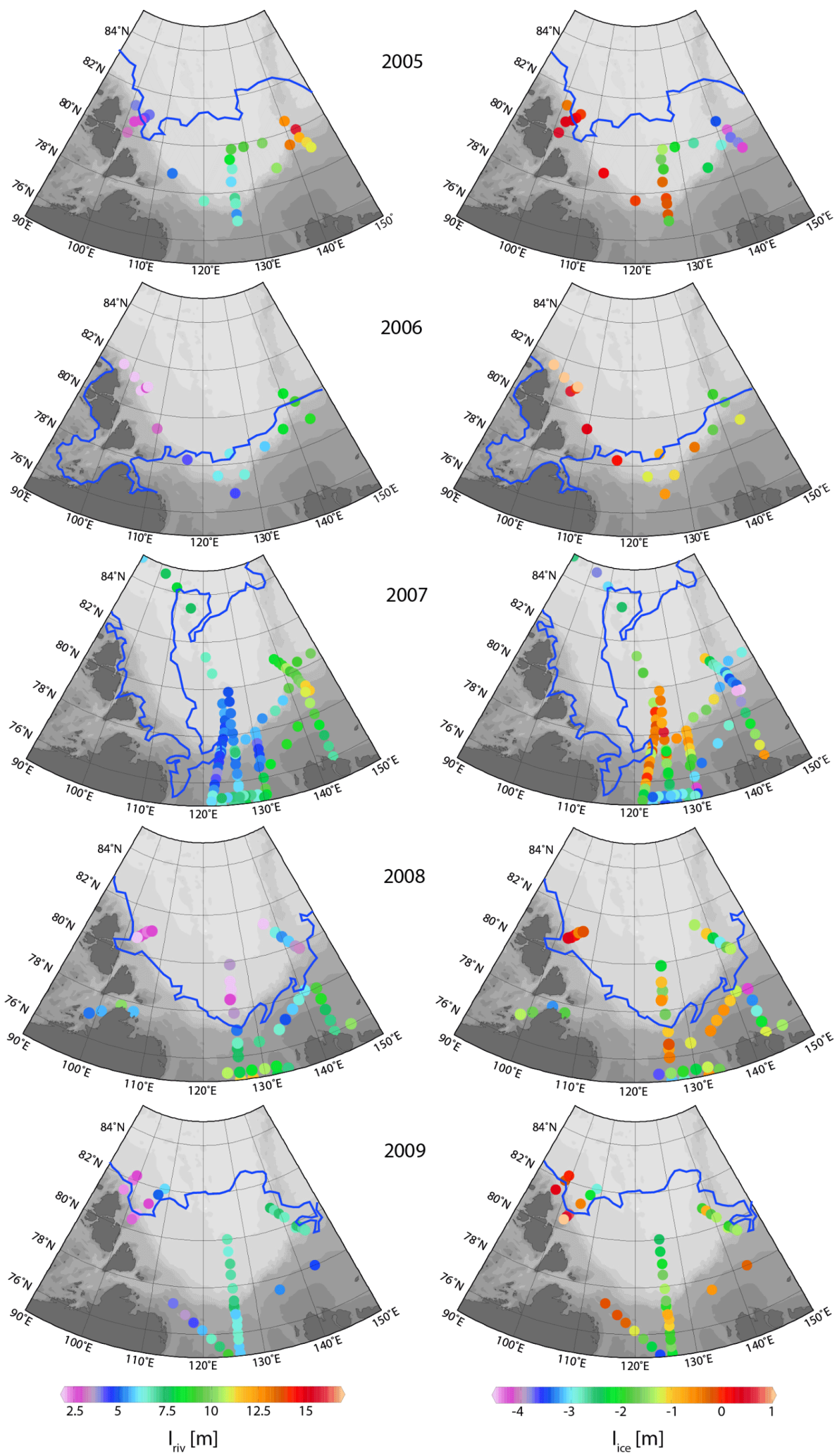

Fig. 5. Integrals of river and sea-ice meltwater fractions over the upper $150 \mathrm{~m}$ of the water column. Also shown in blue is the sea-ice edge on 15 Sep. based on daily sea-ice concentration data from Bremen University (Advanced Microwave Scanning Radiometer-EOS (AMSR-E); Spreen et al., 2008). 
Table 3. Property ranges of water masses in the upper $100 \mathrm{~m}$ of the water column at the Laptev Sea continental margin (compare Fig. 6).

\begin{tabular}{|c|c|c|c|c|}
\hline & $\begin{array}{l}\text { Laptev Sea } \\
\text { central shelf } \\
\text { bottom waters } \\
\text { at } 25-50 \mathrm{~m}\end{array}$ & $\begin{array}{l}\text { Cont. slope } \\
\text { at } \sim 126^{\circ} \mathrm{E} \\
\text { slope water } \\
\text { at } 50-80 \mathrm{~m}\end{array}$ & $\begin{array}{l}\text { Basin } \\
\text { at } \sim 126^{\circ} \mathrm{E} \\
\text { LHW } \\
\text { at } 25-50 \mathrm{~m}\end{array}$ & $\begin{array}{l}\text { Basin } \\
\sim 142^{\circ} \mathrm{E} \\
\mathrm{LSHW} \\
\text { at } 25-50 \mathrm{~m}\end{array}$ \\
\hline$f_{\text {SIM }}[\%]$ & $\sim-10$ & $\sim-4$ to 0 & $\sim-2$ to -5 & $\sim-2$ to -7 \\
\hline $\mathrm{Si}\left[\mu \mathrm{mol} \mathrm{kg} \mathrm{kg}^{-1}\right]$ & 15 to 100 & 10 to 12 & 2 to 6 & 4 to 10 \\
\hline$S$ & 31.5 to 32.5 & 33.1 to 33.9 & 33.1 to 33.8 & 31.4 to 33.7 \\
\hline$T\left[{ }^{\circ} \mathrm{C}\right]$ & $\sim-1.6$ & $\sim-1.5$ to -1.3 & $\sim-1.7$ & $\sim-1.7$ to -1.5 \\
\hline
\end{tabular}

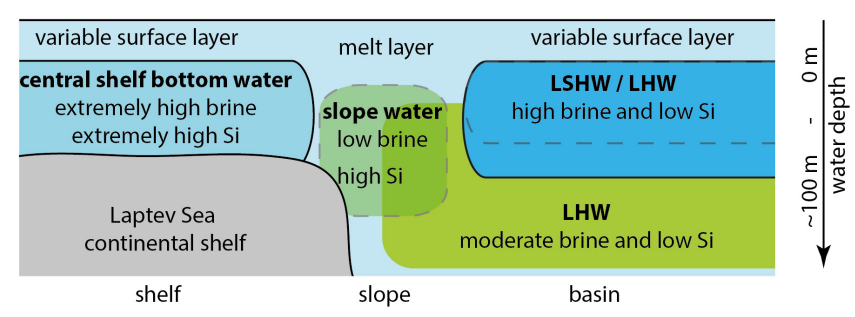

Fig. 6. Sketch of the water mass structure within the halocline on a section across the Laptev Sea continental shelf and slope into the Eurasian Basin. LSHW refers to low-salinity halocline water with $S<33$ that is predominantly found east of $130^{\circ}$ E. LHW refers to Lower Halocline Water with $S \sim 33-34.5$ that also contains a brine signal at $S>33$. For further explanation see text.

in Laptev Sea coastal polynyas that occurs via the easternmost part of the Laptev Sea (Bauch et al., 2009), not continuously but in pulses (Bauch et al., 2011a, b; Karcher et al., 2006), in response to atmospheric forcing (Guay et al., 2001; Dmitrenko et al., 2008; Bauch et al., 2011a). Nevertheless, river water fractions in surface waters of the western Laptev Sea continental slope are still up to $\sim 8 \%$ (at $S \sim 32-34$ ) and $\sim 15 \%$ (at $S \sim 31-29$ ) (Fig. 7). Where do these signals come from given the general eastward advection in this area? It is known that $\mathrm{Ob}$ and Yenisei river water does not leave the Kara Sea northwards but flows around Taymyr Peninsula directly through Vilkitsky Strait into the northwestern Laptev Sea (Bauch et al., 2011b). Hence, the river water found in surface waters at the continental slope of the western Laptev $\mathrm{Sea}$ is likely entirely $\mathrm{Ob}$ and Yenisei river water.

\subsection{Relation between sea-ice melt and ice edge}

At the continental slope of the western and central Laptev Sea, SIM fractions are mostly positive and reflect a surplus of sea-ice melt in the area (Fig. 7, see orange circles). All SIM fractions are net signals. Therefore, a negative $f_{\text {SIM }}$ from the winter season may be overprinted by sea-ice melt of the current summer season. As Arctic shelves are regions of seaice export, SIM values remain largely negative on the shelf also during summer (Bauch et al., 2005). On the Laptev Sea shelf the retreat of the seasonal ice cover is governed by wind forcing (Bareiss et al., 1999) and sea-ice melt is found only in correlation with elevated river water fractions in years with a pronounced river plume (Bauch et al., 2013). Hence, sea-ice melt on the shelf may originate solely from initial breakup of the fast-ice (Bauch et al., 2013) triggered by the river plume in the southeastern Laptev Sea (Bareiss et al., 1999). In contrast to the shelf, positive $f_{\text {SIM }}$ are generally observed in surface waters at the Laptev Sea continental slope (Fig. 3). SIM inventory values along the western and central continental slope are consistently positive in all years (Fig. 5), while they are mostly negative north and south of the shelf break (Fig. 5). At the eastern Laptev Sea continental slope, SIM inventories are consistently negative because waters with a surplus of sea-ice related brines (negative $f_{\text {SIM }}$ ) leave the shelf through this region (Bauch et al., 2009, 2011b).

Because sampling in all years was conducted in September close to the general minimum of the summer ice extent, a maximum input of sea-ice melt to surface waters can be expected from the current summer season and should be reflected in considerable sea-ice melt contributions (positive SIM) at the surface at and south of the ice edge. Surprisingly the ice edge on 15 September shows no apparent correlation or pattern with SIM inventory values (Fig. 5). This indicates that the sea-ice cover near the continental slope is not primarily controlled by local sea-ice melting. A single station taken near Severnaya Zemlya in 2009 shows a $34 \mathrm{~m}$ thick low salinity layer with $28-30 \%$ sea-ice meltwater (see Fig. 7). Such a pronounced locally restricted meltwater layer is likely to be strongly influenced by local melting, but consistently positive SIM inventory values are found even below the ice cover north of Severnaya Zemlya in 2006 (Fig. 5). It therefore seems reasonable to argue that the positive SIM signal along the western and central Laptev Sea continental margin is primarily of distal origin. This signal may be to a large degree fed by lateral advection of waters within the halocline and the upper $50 \mathrm{~m}$ along the continental slope from west to east, from the northern Kara Sea or the Barents Sea. Such an advection is consistent with a shelf break branch of the Arctic Continental Boundary Current (Aksenov et al., 2011; Dmitrenko et al., 2012). 


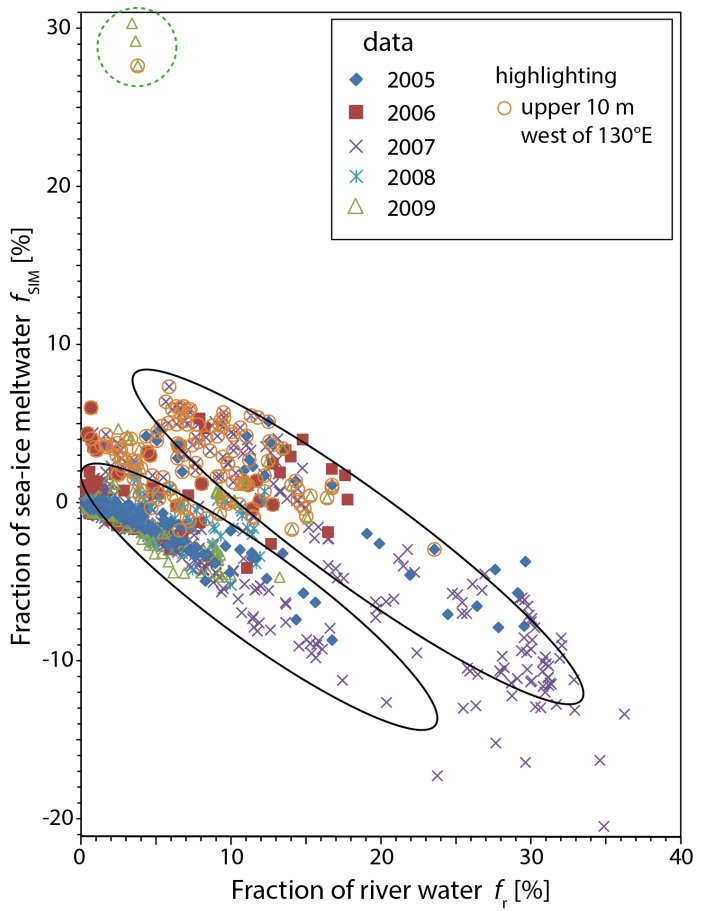

Fig. 7. Fractions of sea-ice meltwater $\left(f_{\mathrm{i}}\right)$ versus fractions of river water $\left(f_{\mathrm{r}}\right)$ for the upper $150 \mathrm{~m}$ of the water column for NABOS 2005-2009 and PS07 data at the Laptev Sea continental margin (Fig. 1). Clusters within $f_{\mathrm{SIM}} / f_{\mathrm{r}}$ correlations are highlighted with ellipses. Orange circles highlight the upper $10 \mathrm{~m}$ on the western Laptev Sea slope (west of $130^{\circ} \mathrm{E}$ and north of $76.5^{\circ} \mathrm{N}$ ). The stippled circle highlights anomalous data from the upper $30 \mathrm{~m}$ from a station north of Severnaya Zemlya (KD-67-09; $101.8^{\circ} \mathrm{E}, 80.4^{\circ} \mathrm{N}$; samples were taken at 5, 11 and $26 \mathrm{~m}$ water depth; CTD data show a sharp increase in salinity, with $\sim 25$ at $0-34 \mathrm{~m}$ to 28 at $35 \mathrm{~m}$, and 34 at $36 \mathrm{~m})$.

\subsection{Laptev Sea export of silicate and N / P signatures}

Extremely high silicate concentrations are observed on the Laptev Sea shelf (Fig. 3). The silicate maximum found at the bottom on the continental slope within the salinity range of the LHW could therefore originate from an addition of these high silicate Laptev Sea bottom waters (Dmitrenko et al., 2011). In the following chapter this hypothesis will be further discussed.

The Lena River has extremely high silicate concentrations (Si) with up to $4 \mathrm{mg} \mathrm{Si} \mathrm{L}^{-1}\left(\sim 140 \mu \mathrm{mol} \mathrm{L}^{-1}\right)$, similar to high silicate and nutrient values of most Arctic rivers such as the $\mathrm{Ob}$ and Yenisei (Holmes et al., 2012). Due to the relative excess of silicate, biological processes in the Laptev Sea are limited by nitrate $(\mathrm{N})$ and phosphate $(\mathrm{P})$. Once $\mathrm{N}$ and $\mathrm{P}$ are depleted, high Si concentrations still remain in waters with high fractions of river water. $\mathrm{Si}$ is therefore a good indicator for Lena River water within the surface layer (Wegner et al., 2013; Pivovarov et al., 2004). But Si as well as N and $\mathrm{P}$ concentrations show also a local maximum at the bottom within the Laptev Sea bottom layer (Pivovarov et al., 2004; see also Si within Fig. 3, N and P not shown). High nutrient concentrations at depth result from remineralisation and dissolution of sinking particles, as well as from resuspension at the sediment-water interface (Santschi et al., 1990). This nutrient regeneration explains the coincident distribution of the maxima of $\mathrm{Si}$ and the sea-ice related brine signal (negative SIM) within the Laptev Sea bottom layer, although the processes that produce each signal are clearly different. That is, the Si and nutrient maxima within the bottom layer likely originate at the sediment-water interface, possibly over the entire Laptev Sea shelf and slope area. The signal of seaice related brine (negative SIM) is instead introduced to the whole water column within the polynya region (Fig. 1) on the central Laptev Sea shelf during winter. Within the bottom layer, however, this brine signal remains unaltered by surface summer processes (Bauch et al., 2013). In fact, the $\mathrm{Si}$ maxima found at $126^{\circ} \mathrm{E}$ near the bottom of the continental slope are not accompanied by a significant sea-ice related brine signal (negative SIM; Fig. 3). The brine signal on the central Laptev Sea shelf largely ceases at the continental slope, slightly further south of the Si maxima (Fig. 3). An exception is the Si maximum observed in 2005 together with a pronounced negative SIM signal and relatively high salinity of $S \sim 33.5$. In all years the observed $\mathrm{Si}$ values of $\sim 10 \mu \mathrm{mol} \mathrm{L}{ }^{-1}$ within the maxima at the continental slope (Table 2) are considerably lower than concentrations found in Laptev Sea bottom waters, but they are significantly higher than the concentrations of $\sim 6 \mu \mathrm{mol} \mathrm{L} \mathrm{L}^{-1}$ found in the Atlantic Water core within the Eurasian Basin (Bauch et al., 1995). The missing brine signature excludes the central Laptev Sea as the source of the Si maximum, which instead might be formed locally at the continental slope, on the outer shelf or it might be advected from the west with the general water transport (e.g. Woodgate et al., 2001; Newton et al., 2008; Aksenov et al., 2011).

The nitrate to phosphate relationship ( $\mathrm{N} / \mathrm{P}$ ratio) can be additionally used as an indicator for the origin of a water mass. On average $\mathrm{N}$ and $\mathrm{P}$ change at a ratio of $\sim 16: 1$ (i.e., Redfield ratio) during biological production and remineralisation of organic matter. On the continental shelves this ratio can strongly deviate from the Redfield stoichiometry (e.g. Broecker and Peng, 1982; Nitishinski et al., 2007). In the Arctic Ocean, deviations from the N / P typical of Atlantic waters (Bauch et al., 2011b) are the result of denitrification processes in Pacific derived waters (e.g., Jones et al., 2008; see Fig. 8) and in shelf waters influenced by bottom sediments processes on the Bering and Chukchi shelves (Devol et al., 1997; Tanaka et al., 2004; Yamamoto-Kawai et al., 2006), the East Siberian Sea (Anderson et al., 2013) and the Laptev Sea (Bauch et al., 2011b). N / P values from systematic sampling campaigns on the Laptev Sea shelf conducted in 2007, 2010, and 2011 strongly deviate from the Atlantic $\mathrm{N} / \mathrm{P}$ relation within the salinity range of central Laptev Sea bottom waters (Fig. 9a). Denitrification in Laptev Sea bottom 


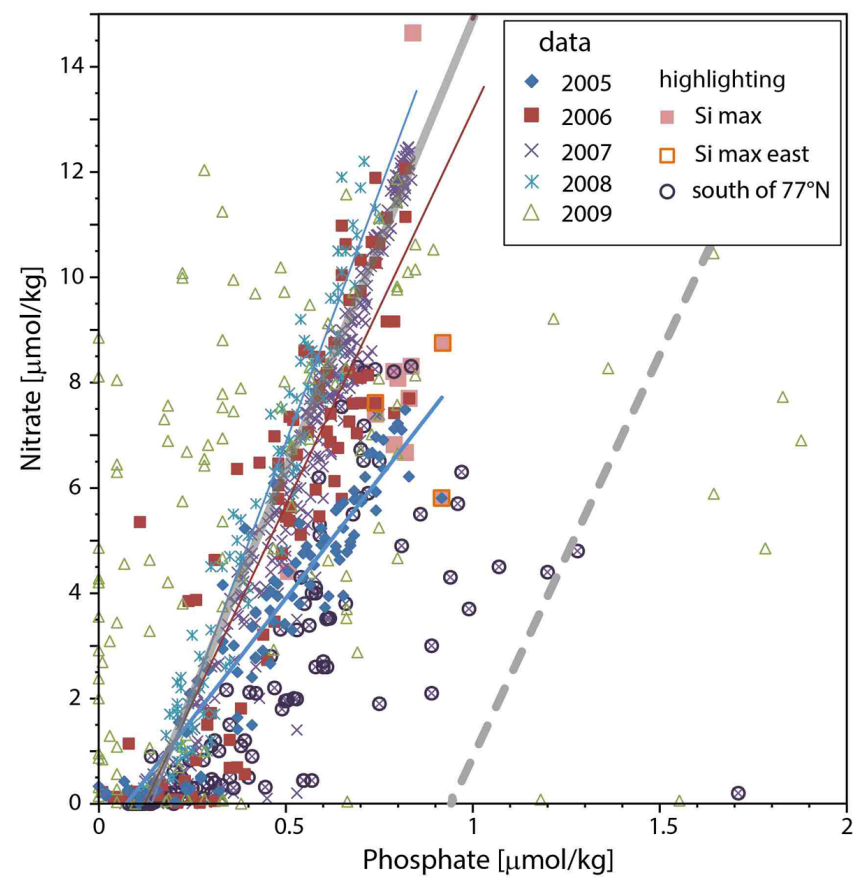

Fig. 8. N / P correlation for the upper $150 \mathrm{~m}$ of the water column for NABOS 2005-2009 and PS07 data at the Laptev Sea continental margin (Fig. 1). Indicated are an Atlantic N / P relation (solid gray line with $\mathrm{N}=16.785 \cdot \mathrm{P}-1.9126$ after Bauch et al., 2011a) and for reference, also a Pacific N / P relation is shown (broken line with $\mathrm{N}=15.314 \cdot\left[\mathrm{PO}_{4}\right]-14.395$ after Jones et al., 2008). Also indicated are linear correlations for data sets taken in 2005, 2006 and 2008 in corresponding colors. Linear correlation for 2007 shelf break data is identical to the Atlantic N / P relation. Note that data from 2005 show a systematic deviation from the Atlantic Water $\mathrm{N} / \mathrm{P}$ correlation, that we believe to be a systematic error in $\mathrm{N}$ measurements. N / P values from 2009 data show unsystematic scatter and are disregarded.

waters can be identified using the deviation relative to the Atlantic N / P relation $\left(\mathrm{N}_{\mathrm{Atl}}^{*}=\mathrm{N}-16.835 \cdot \mathrm{P}+1.918\right.$ after Gruber and Sarmiento, 1997; Fig. 9b). Denitrification $\mathrm{N}_{\text {Atl }}^{*}$ occurs mainly on the central Laptev Sea shelf (Fig. 9b).

The N / P signatures observed north of the Laptev Sea continental slope are all close to the Atlantic N / P ratio (Fig. 8), while bottom waters on the Laptev Sea shelf show a signal consistent with denitrification (Figs. 9 and 8, shelf stations). The N/P ratios within the Si maximum at the Laptev Sea continental slope show little or no deviation from the Atlantic $\mathrm{N} / \mathrm{P}$ line (Fig. 8, pink squares) and therefore give no indication for a potential origin of these waters on the central Laptev Sea shelf. In 2005, when the Si maximum at the central Laptev Sea slope is coincident with a SIM signal, there is also no denitrification signal relative to the overall $2005 \mathrm{~N} / \mathrm{P}$ ratio (Fig. 8). Only at the eastern continental slope, where the outflow of waters from the central Laptev Sea occurs, the $\mathrm{N} / \mathrm{P}$ ratios within the Si maximum show a slight denitrification signal in all years (Fig. 8, framed pink squares).
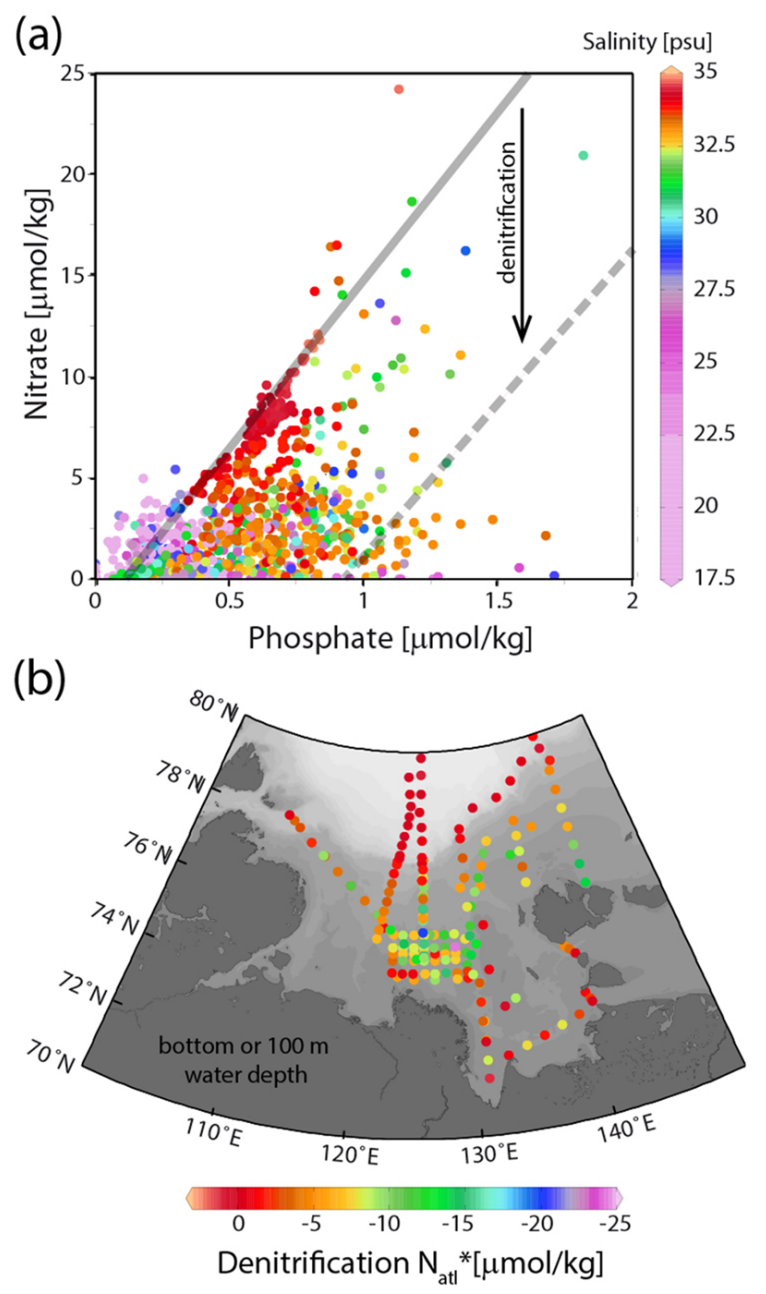

Fig. 9. (a) Nitrate versus phosphate for shelf waters and upper $100 \mathrm{~m}$ for stations taken during PS07 and VB07 in summer 2007 (upper panel). The salinity of each sample is indicated by colour. The gray line shows the Atlantic N / P relation. (b) Denitrification signal $\mathrm{N}_{\mathrm{Atl}}^{*}$ calculated as deviation relative to the Atlantic N / P relation $\left(\mathrm{N}_{\mathrm{Atl}}^{*}=\mathrm{N}-16.835 \cdot \mathrm{P}+1.918\right)$ for bottom waters or $100 \mathrm{~m}$ water depth. Note that $\mathrm{N}_{\text {Atl }}^{*}$ is similar to $\mathrm{N}^{*}$ calculated by Gruber and Sarmiento (1997) relative to global N / P values. For further explanation see text.

The missing brine contribution within the silicate maximum at the central continental slope excludes the central Laptev Sea shelf as a potential source, where high silicate bottom waters but also high sea-ice related brine signals are found. The N/P signature within the Si maximum at the continental slope (Fig. 8, pink squares) yields no conclusive evidence for the potential origin of these waters within the Laptev Sea. 


\section{Conclusions}

A frontal system is inferred between shelf waters, continental slope waters and basin waters within the Lower Halocline Water (LHW) and low-salinity halocline water (LSHW) along the continental slope of the Laptev Sea (Fig. 6). $\delta^{18} \mathrm{O}$ derived signals of river water and sea-ice related brine as well as nutrient ratios $(\mathrm{N} / \mathrm{P})$ and signatures from sedimentbottom water denitrification processes $\left(\mathrm{N}_{\mathrm{Atl}}^{*}\right)$ are found indicative of central Laptev Sea shelf bottom waters and are important for the assignment of shelf, slope and basin water masses of the upper water column along the Laptev Sea continental margin. Net sea-ice meltwater fractions and inventories show no apparent relationship with the summer ice extent. Instead sea-ice inventories are consistently positive over the continental slope and the summer sea-ice meltwater distribution at the continental margin appears to be influenced by advection from west to east along the Laptev Sea continental slope. In addition to the along-slope frontal system we see a strong zonal gradient on the shelf at $\sim 122-126^{\circ} \mathrm{E}$ with a sharp eastward increase in river water and sea-ice related brine signal. Both river water and sea-ice related brine cross the Laptev Sea shelf break at $\sim 140^{\circ}$ E, and feed the LSHW with salinities below $\sim 33$ in the upper $50 \mathrm{~m}$ of the water column.

There is no evidence for an entrainment of Laptev Sea shelf waters at higher salinities into the LHW at the Laptev Sea continental margin. The silicate maximum found within the salinity range of LHW at the continental slope cannot originate on the central Laptev Sea shelf as it does not show the appropriate sea-ice related brine signature. In addition, the nitrate to phosphate ratio $(\mathrm{N} / \mathrm{P})$ at the silicate maximum shows no denitrification signal, which contrasts with central Laptev Sea bottom waters. Our data indicate that the silicate maximum and $\mathrm{N} / \mathrm{P}$ signatures at the slope either form locally, on the outer Laptev Sea shelf, or are advected from elsewhere (Dmitrenko et al., 2011, 2012). Similar to the advection of the sea-ice melt signal along the Laptev Sea continental margin, it seems likely that the silicate signal within the LHW at the continental slope is also fed by lateral advection. Such a lateral advection of water along the continental slope may explain the frontal system between shelf, continental slope and basin that is identified at the central Laptev Sea continental margin (Fig. 6). Further quantitative studies with numerical and dynamical approaches may help to evaluate these results in a broader context.

With ongoing climate change, considerable alterations within the Laptev Sea shelf environment are to be expected, with likely impact on sea-ice processes. With the potential of further freshening due to increased amounts of river discharge and precipitation (Zhang et al., 2013), the formation mode of brine-enriched bottom waters on the Laptev Sea shelf may be significantly altered (Bauch et al., 2010). With surface freshening, brine-enriched waters are less likely to reach the shelf's bottom layer (Bauch et al., 2012), thus leaving a relatively high salinity bottom layer due to the missing river runoff input (Bauch et al., 2010, 2013). Our results thus indicate that with a further freshening, the export of Laptev Sea brine-enriched shelf waters to the Arctic Ocean halocline is to be expected at overall lower salinities and still within LSHW below $\sim 33$. Although salinity in Laptev Sea bottom water potentially increases with surface freshening, whether or not Laptev Sea bottom water reaches the density layer of LHW is less straightforward and further investigations are needed.

Acknowledgements. We thank all members of the NABOS project for exceptional working conditions and extensive support during expeditions. Nutrient data from NABOS expedition in 2009 were provided under the lead of P. Makkakeev (Shirshov Institute, Moscow). Nutrient data in 2007 and 2008 were taken as part of the Natural Environment Research Council (UK) funded Arctic Synoptic Basin-wide Oceanography (ASBO) IPY consortium grant. D. Bauch acknowledges funds from the German Research Foundation grants SP $526 / 3$ and BA $1689 / 2-1$ as well as grant 03G0639D funded by the BMBF within the German-Russian cooperation "Laptev Sea System". A. Novikhin acknowledges funding through the Federal Ministry of Education and Research project Otto-Schmidt-Laboratory for Polar and Marine Sciences. I. Polyakov thanks NSF, CIFAR, JAXA and JAMSTERC for support. I. Dmitrenko received financial support from the Canadian Excellence Research Chair (CERC) program and also by the BMBF within the German-Russian cooperation "Laptev Sea System" under grant 03G0639A. We thank all colleagues of these projects. Plots were made with Ocean Data View (ODV) (Schlitzer, 2001) and Generic Mapping Tools (GMT) software (Wessel and Smith, 1998). Reviews by R. Newton and P. Schlosser are gratefully acknowledged.

The service charges for this open access publication have been covered by a Research Centre of the Helmholtz Association.

Edited by: M. Meier

\section{References}

Aagaard, K., Coachman, L. and Carmack, E.: On the halocline of the Arctic Ocean, Deep-Sea Res., 28, 529-545, 1981.

Abrahamsen, E. P., Meredith, M. P., Falkner, K. K., Torres-Valdes, S., Leng, M. J., Alkire, M. B., Bacon, S., Laxon, S., Polyakov, I., Ivanov, V., and Kirillov, S.: Tracer-derived freshwater budget of the Siberian Continental Shelf following the extreme Arctic summer of 2007, Geophys. Res. Lett., 36, L07602, doi:10.1029/2009GL037341, 2009.

Aksenov, Y., Ivanov, V. V., Nurser, A. J. G., Bacon, S., Polyakov, I. V., Coward, A. C., Naveira-Garabato, A. C., and BeszczynskaMoeller, A.: The Arctic Circumpolar Boundary Current, J. Geophys. Res.-Oceans, 116, C09017, doi:10.1029/2010JC006637, 2011.

Anderson, L. G., Andersson, P. S., Björk, G., Peter Jones, E., Jutterström, S., and Wåhlström, I.: Source and formation of the up- 
per halocline of the Arctic Ocean, J. Geophys. Res.-Oceans, 118, 410-421, doi:10.1029/2012JC008291, 2013.

Bareiss, J., Eicken, H., Helbig, A., and Martin, T.: Impact of river discharge and regional climatology on the decay of sea ice in the Laptev Sea during spring and early summer, Arct. Antarct. Alp. Res., 31, 214- 229, 1999.

Bauch, D., Schlosser, P., and Fairbanks, R. F.: Freshwater balance and the sources of deep and bottom waters in the Arctic Ocean inferred from the distribution of $\mathrm{H}_{2}^{18} \mathrm{O}$, Progr. Oceanogr., 35, 5380, 1995.

Bauch, D., Erlenkeuser, H., and Andersen, N.: Water mass processes on Arctic shelves as revealed from ${ }^{18} \mathrm{O}$ of $\mathrm{H}_{2} \mathrm{O}$, Global Planet. Change, 48, 165-174, doi:10.1016/j.gloplacha.2004.12.011, 2005.

Bauch, D., Dmitrenko, I. A., Wegner, C., Hölemann, J., Kirillov, S. A., Timokhov, L. A., and Kassens, H.: Exchange of Laptev Sea and Arctic Ocean halocline waters in response to atmospheric forcing, J. Geophys. Res.-Oceans, 114, C05008, doi:10.1029/2008JC005062, 2009.

Bauch, D., Hölemann, J., Andersen, N., Dobrotina, E., Nikulina, A., and Kassens, H.: The Arctic shelf regions as a source of freshwater and brine-enriched waters as revealed from stable oxygen isotopes, Polarforschung, 80, 127-140, 2010.

Bauch, D., Gröger, M., Dmitrenko, I., Hölemann, J., Kirillov, S., Mackensen, A., Taldenkova, E., and Andersen, N.: Atmospheric controlled freshwater water release at the Laptev Sea Continental margin, Polar Res., 30, 5858, doi:10.3402/polar.v30i0.5858, 2011a.

Bauch, D., Rutgers van der Loeff, M., Andersen, N., TorresValdes, S., Bakker, K., and Abrahamsen, E. P.: Origin of freshwater and polynya water in the Arctic Ocean halocline in summer 2007, Progr. Oceanogr., 91, 482-495, doi:10.1016/j.pocean.2011.07.017, 2011 b.

Bauch, D., Hölemann, J. A., Dmitrenko, I. A., Janout, M. A., Nikulina, A., Kirillov, S. A., Krumpen, T., Kassens, H., and Timokhov, L.: The impact of Siberian coastal polynyas on shelfderived Arctic Ocean halocline waters, J. Geophys. Res.-Oceans, 117, C00G12, doi:10.1029/2011JC007282, 2012.

Bauch, D., Hölemann, J. A., Nikulina, A., Wegner, C., Janout, M. A., Timokhov, L. A., and Kassens, H.: Correlation of river water and local sea-ice melting on the Laptev Sea shelf (Siberian Arctic), J. Geophys. Res.-Oceans, 118, 550-561, doi:10.1002/jgrc.20076, 2013.

Bordovsky, O. K. and Ivanenkov, V. N.: Modern methods of hydrochemical studies of the ocean, IORAS, Moscow, 1992.

Broecker, W. S. and Peng, T. H.: Tracers in the Sea, Eldigio, Palisades, NY, 1982.

Cooper, L. W., Whitledge, T. E., Grebmeier, J. M., and Weingartner, T.: The nutrient, salinity, and stable isotope composition of Bering and Chukchi seas waters in and near the Bering Strait, J. Geophys. Res., 102, 12563-12573, 1997.

Craig, H.: Standard for reporting concentrations of Deuterium and Oxygen-18 in natural waters, Science, 133, 1833-1834, 1961.

Devol, A. H., Codispoti, L. A., and Christensen, J. P.: Summer and winter denitrification rates in western Arctic shelf sediments, Cont. Shelf Res., 17, 1029-1050, doi:10.1016/S02784343(97)00003-4, 1997.

Dmitrenko, I. A., Kirillov, S. A., and Tremblay, L. B.: The long-term and interannual variability of summer fresh wa- ter storage over the eastern Siberian shelf: Implication for climatic change, J. Geophys. Res.-Oceans, 113, C03007, doi:10.1029/2007JC004304, 2008.

Dmitrenko, I. A., Kirillov, S. A., Tremblay, L. B., Bauch, D., Hölemann, J. A., Krumpen, T., Kassens, H., Wegner, C., Heinemann, G., and Schröder, D.: Impact of the Arctic Ocean Atlantic Water layer on Siberian shelf hydrography, J. Geophys. Res.-Oceans, 115, C08010, doi:10.1029/2009JC006020, 2010.

Dmitrenko, I. A., Ivanov, V. V., Kirillov, S. A., Vinogradova, E. L., Torres-Valdes, S., and Bauch, D.: Properties of the Atlantic derived halocline waters over the Laptev Sea continental margin: Evidence from 2002 to 2009, J. Geophys. Res.-Oceans, 116, C10024, doi:10.1029/2011JC007269, 2011.

Dmitrenko, I. A., Kirillov, S. A., Ivanov, V. V., Rudels, B., Serra, N., and Koldunov, N. V.: Modified Halocline Water over the Laptev Sea Continental Margin: Historical Data Analysis, J. Climate, 25, 5556-5565, doi:10.1175/JCLI-D-11-00336.1, 2012.

Ekwurzel, B., Schlosser, P., Mortlock, R., and Fairbanks, R.: River runoff, sea ice meltwater, and Pacific water distribution and mean residence times in the Arctic Ocean, J. Geophys. Res.-Oceans, 106, 9075-9092, 2001.

Gruber, N. and Sarmiento, J. L.: Global patterns of marine nitrogen fixation and denitrification, Global Biogeochem. Cy., 11, 235266, 1997.

Guay, C. K., Falkner, K. K., Muench, R. D., Mensch, M., Frank, M., and Bayer, R.: Wind-driven transport pathways for Eurasian Arctic river discharge, J. Geophys. Res., 106, 11469-11480, 2001.

Holmes, R. M., McClelland, J. W., Peterson, B. J., Tank, S. E., Bulygina, E., Eglington, T. I., Gordeev, V. V., Gurtovaya, T. Y., Raymond, P. A., Repeta, R., Staples, R., Striegl, R. G., Zhulidov, A. V., and Zimov, S. A.: Seasonal and annual fluxes of nutrients and organic matter from large rivers to the Arctic Ocean and surrounding seas, Estuaries Coasts, 35, 369-382, doi:10.10007/s12237-011-9386-6, 2012.

Jones, E., Anderson, L., and Swift, J.: Distribution of Atlantic and Pacific water in the upper Arctic Ocean: Implications for circulation, Geophys. Res. Lett., 25, 765-768, 1998.

Karcher, M., Gerdes, R., and Kauker, F.: Modeling of ?180 and 99Tc dispersion in Arctic and subarctic seas, ASOF Newsletter, Issue No 5, April 2006, available at: http://epic.awi.de/epic/ Main?static=yes\&page=abstract\&entry_dn=Kar2006d, 2006.

Kassens, H. and Dmitrenko, I. A.: The TRANSDRIFT II expedition to the Laptev Sea, Rep. Polar Res., 182, 1-180, 1995.

Kassens, H. and Volkmann-Lark, K.: Eurasische Schelfmeere im Umbruch Ozeanische Fronten und Polynjasysteme in der LaptevSee, 2010.

Krumpen, T., Janout, M., Hodges, K. I., Gerdes, R., GirardArdhuin, F., Hölemann, J. A., and Willmes, S.: Variability and trends in Laptev Sea ice outflow between 1992-2011, The Cryosphere, 7, 349-363, doi:10.5194/tc-7-349-2013, 2013.

Macdonald, W., Paton, D., Carmack, E., and Omstedt, A.: The freshwater budget and under-ice spreading of Mackenzie River water in the Canadian Beauford Sea based on salinity and ${ }^{18} \mathrm{O} /{ }^{16} \mathrm{O}$ measurements in water and ice, J. Geophys. Res.Oceans, 100, 895-919, 1995.

Newton, R., Schlosser, P., Martinson, D. G., and Maslowski, W.: Freshwater distribution in the Arctic Ocean: Simulation with a high resolution model and model-data comparison, J. Geophys. Res.-Oceans, 113, C05024, doi:10.1029/2007JC004111, 2008. 
Newton, R., Schlosser, P., Mortlock, R., Swift, J., and MacDonald, R.: Canadian Basin freshwater sources and changes: Results from the 2005 Arctic Ocean Section, J. Geophys. Res.-Oceans, 118, 2133-2154, doi:10.1002/jgrc.20101, 2013.

Nitishinsky, M., Anderson, L. G., and Hölemann, J. A.: Inorganic carbon and nutrient fluxes on the Arctic Shelf, Cont. Shelf Res., 27, 1584-1599, doi:10.1016/j.csr.2007.01.019, 2007.

Östlund, H. and Hut, G.: Arctic Ocean water mass balance from isotope data, J. Geophys. Res.-Oceans, 89, 6373-6381, 1984.

Overland, J. E. and Wang, M.: When will the summer arctic be nearly sea ice free? Geophys. Res. Lett., 40, 1-5, doi:10.1002/grl.50316, 2013.

Pivovarov, S. V., Hölemann, J. A., Kassens, H., Piepenburg, D., and Schmidt, M. K.: Laptev and East Siberian Seas, in: The Sea, edited by: Robinson, R. A. and Brink, K. H., 14, 1107-1133, Harvard University Press, 2004.

Rudels, B.: Atlantic sources of the Arctic Ocean surface and halocline waters, Polar Res., 23, 181-208, 2004.

Rudels, B., Anderson, L. G., and Jones, E. P.: Formation and evolution of the surface mixed layer and halocline of the Arctic Ocean, J. Geophys. Res.-Oceans, 101, 8807-8821, doi:10.1029/96JC00143, 1996.

Santschi, P., Höhener, P., Benoit, G., and Buchholtz-ten Brink, M.: Chemical processes at the sediment-water interface, Marine Chem., 30, 269-315, doi:10.1016/0304-4203(90)90076-O, 1990.

Schauer, U.: The expedition ARKTIS-XXII/2 of the research vessel "Polarstern" in 2007, Alfred-Wegener Institute for Polar and Marine Research, Bremerhaven, 2008.

Schlitzer, R.: Ocean Data View, available at: http://www. awi-bremerhaven.de/GEO/ODV, 2001.

Spreen, G., Kaleschke, L., and Heygster, G.: Sea ice remote sensing using AMSR-E 89-GHz channels, J. Geophys. Res.-Oceans, 113, C02S03, doi:10.1029/2005JC003384, 2008.

Steele, M. and Boyd, T.: Retreat of the cold halocline layer in the Arctic Ocean, J. Geophys. Res.-Oceans, 103, 10419-10435, 1998.
Tanaka, T., Guo, L., Deal, C., Tanaka, N., Whitledge, T., and Murata, A.: $\mathrm{N}$ deficiency in a well-oxygenated cold bottom water over the Bering Sea shelf: influence of sedimentary denitrification, Cont. Shelf Res., 24, 1271-1283, doi:10.1016/j.csr.2004.04.004, 2004.

US Environmental Protection Agency: Methods of chemical analysis of water and wastes, Cincinnati, Ohio, EPA 600/4-79/020, p. 460, 1983.

Wegner, C., Bauch, D., Hölemann, J. A., Janout, M. A., Heim, B., Novikhin, A., Kassens, H., and Timokhov, L.: Interannual variability of surface and bottom sediment transport on the Laptev Sea shelf during summer, Biogeosciences, 10, 11171129, doi:10.5194/bg-10-1117-2013, 2013.

Wessel, P. and Smith, W. H. F.: New improved version of the Generic Mapping Tools released, EOS Trans. AGU, 79, 579, 1998.

Woodgate, R. A., Aagaard, K., Muench, R. D., Gunn, J., Björk, G., Rudels, B., Roach, A. T., and Schauer, U.: The Arctic Ocean Boundary Current along the Eurasian slope and the adjacent Lomonosov Ridge: Water mass properties, transports andtransformations from mooredinstruments, Deep-Sea Res. I, 48, 1757 1792, 2001.

Yamamoto-Kawai, M., Carmack, E., and McLaughlin, F.: Nitrogen balance and Arctic throughflow, Nature, 443, 43-43, doi:10.1038/443043a, 2006.

Yamamoto-Kawai, M., McLaughlin, F. A., Carmack, E. C., Nishino, S., and Shimada, K.: Freshwater budget of the Canada Basin, Arctic Ocean, from salinity, $\delta^{18} \mathrm{O}$, and nutrients, J. Geophys. Res.-Oceans, 113, C01007, doi:10.1029/2006JC003858, 2008

Zhang, X., He, J., Zhang, J., Polyakov, I., Gerdes, R., Inoue, J., and $\mathrm{Wu}, \mathrm{P}$.: Enhanced poleward moisture transport and amplified northern high-latitude wetting trend, Nature Clim. Change, 3, 47-51, doi:10.1038/nclimate1631, 2013. 